\title{
When Balkan became Popular: The Role of Cultural INTERMEdiaRies IN COMmunicating Regional MUSics
}

\author{
Andreas Gebesmair
}

\section{Introduction}

In a globalized world we take the presence of regional musics in Western markets for granted. World music festivals, specialized radio channels, offline and online shops offer us genres and artists from distant regions. But there is much more music in the world than the few pieces which eventually succeed on world music markets. Music and artists have to fulfill some requirements in order to become popular among Western listeners. What are the prerequisites for popularity beyond the regional, »original « or "primordial context? Why do some musics cross over to Western markets while others do not?

In public as well as in academic discussions of popular music we encounter two widespread explanations of crossover success: Success of niche products on mainstream markets is attributed either to aesthetic characteristics or to changes in demand. Of course, changes in demand provide new opportunities for artists, and aesthetic concessions to widespread listening habits help them to succeed. Nevertheless, it remains to be clarified why at a certain moment music from a certain niche becomes popular on larger markets, while many other acts exhibiting the same characteristics remain unknown.

In this article I argue that so-called cultural intermediaries play an important role in communicating regional music to Western listeners. Regional music does not travel by itself. It requires support by brokers who provide access to crucial resources and frame it in a way which resonates with a broader audience. Using material from the Austrian world music scene I will show how cultural intermediaries helped Balkan music and musicians to 
attract new listeners. During the first decade of the new millennium Balkan music gained considerable popularity in Austria. The number of events, artists and recordings with reference to Balkan music increased significantly due to the activities of cultural intermediaries.

\section{Conventional Explanations of Crossover Success}

When explaining success of regional musics on larger markets, scholars as well as ordinary listeners usually refer to either their particular symbolic form or to changes in the structure of society and therefore changes in demand. Let us begin with the first assumption. The reason why some regional musics cross over to the Western markets is, in this view, their hybridity, i.e. the integration of popular musical forms in traditional structures that make the music more familiar to mainstream or majority listeners. Of course this explanation holds true for many, if not for most of the successful world music acts. The global triumph of Youssou N'Dour or the Buena Vista Social Club is without doubt a result of adapting to sounds and formulae of Western pop music. Taylor calls these aesthetic concessions strategic inauthenticity (Taylor 1997:125-145). But studies of crossovers by musicologists in different fields challenge this assumption. David Brackett for instance in his analysis of mainstream success of African-American singers, refers to James Brown's »Papa's Got A Brand New Bag«, which makes little concessions to pop conventions and concludes that there is »no consistent correlation between style and popularity« (Brackett 1994: 789). This holds true for many African-American musicians on the US market who were valued in spite of or because of their musical authenticity (e.g. Garofalo 1990). Similarly, many world music acts succeeded although they adhered to their musical traditions (e.g. Taylor 1997, chapter 3).

Those productions that were just repackaged without changing their musical form are very informative. Consider for instance one of the earliest evidences of a global demand for Balkan music: Le Mystère des Voix Bulgares. In 1975 Swiss musicologist Marcel Cellier released a Bulgarian female choir under this title and on his own label Disques Cellier that had been recorded in the 1950s (Buchanan 1997). Actually, this music was not traditional but newly composed and arranged and insofar a hybrid itself. But the crucial point in this case is that Cellier's recordings didn't succeed on global markets until they were re-released in 1986 by the British alternative rock label $4 A D$ and shortly after by the Warner label Nonesuch - with a different 
artwork, the instruments of pop marketing and the support from a powerful corporation.

The same process of reframing led the Gypsy musicians from Wallachia in Romania to fame. Originally recorded and released by ethnomusicologist Laurent Albert in the 1980s (Broughton 2007), these musicians became a major Balkan music success only when they were rediscovered by Stéphan Karo and Michel Winter from the Belgian avant-garde label Crammed Disc and marketed as Taraf de Haïdouks shortly after the end of the Ceaușescu Regime. Both examples show that the reason for success of these musics in Western markets was not an adaptation of their symbolic form but a change of intermediation and communication.

However, even if we admit that most of the crossover hits in some way make concessions to popular musical forms, there are always more hybrids out there than eventually succeed. In methodological terms inferring causes of success from the most successful is not convincing, as many less successful acts may have the same musical features as the crossover hits. Therefore, factors other than the integration of Western musical forms also account for the popularity of regional music on larger markets.

The second widespread explanation of crossover success emphasizes changes in demand. Changes in society as a whole or a kind of zeitgeist should account for an increased interest in authenticity and hence for music from distant regions since the 1980s. Collins and Richard for instance in their early discussion of popular music in West Africa write that the alleged musical authenticity of African music responded to European needs for »antidotes to the less desirable aspects of industrial progress « (Collins/Richards 1989: 21f.; see also van der Lee 1998: 62; Connel/Gibson 2004: 353f.; Haynes 2005: 379f. for similar arguments). More recently, Austrian journalist and author Richard Schuberth (2007) observed a demand for ethnic re-rootedness and re-enchantment and calls the enthusiasm for Balkan music rakishly a »Schlammkur zur Therapie von kleinbürgerlicher Antisepsis« (»a mud therapy against petit bourgoise antisepsis«, translation by A.G.). Unfortunately, these assumptions about listeners' motives are mostly derived from the music they prefer. Insofar these assumptions remain somehow arbitrary since all symbolic objects are ambiguous and so are the motives to love them. There are as many explanations of alleged preferences as there are different symbolic layers in works of art. Empirical evidence of existing motives for listening world music is scarce.

Certainly both, aesthetic characteristics of the cultural goods as well as changes in demand, are important prerequisites for crossover success. Nevertheless, in order to fully understand the process it seems reasonable 
to look at those who literally mediate between production and consumption: the so-called cultural intermediaries.

\section{The Role of Intermediaries in Cultural Communication: Who They Are and What They Do}

The notion of new cultural intermediaries was popularized by the sociologist Mike Featherstone (1991) when he used Bourdieu's term in order to describe occupations that are crucial in building and forming consumer societies. He refers to those activities that changed the cultural landscape in the second half of the $20^{\text {th }}$ century. New cultural intermediaries sactively promote and transmit the intellectuals' lifestyle to a larger audience and collude with the intellectuals to legitimate new fields such as sport, fashion, popular music, and popular culture as valid fields of intellectual analysis« (Featherstone 1991: 44, see also 90-94).

In many discussions that followed there was a lot of confusion pertaining to what this term exactly denotes and to what it adds to our understanding of cultural production. Bourdieu himself uses the term equivocally. At one point he talks about new cultural intermediaries as "youth organizers, play leaders etc. « (Bourdieu 1984: 84), at another as »producers of cultural programmes on TV and radio, (as) critics of >quality - newspapers and magazines and all the writer-journalists and journalist-writers (ibid.: 323f.). Hesmondhalgh (2006: 226) in his critical acclaim of Bourdieu's work restricts the term to those who comment on cultural productions in the media and criticizes those scholars who use it synonymously for all people working in the creative industries. On the other hand new cultural intermediaries obviously play an important role in defining which forms of popular culture have to be regarded as legitimate (see below). Insofar it seems warranted to apply the term not just to critics but to all people in the creative industries who, by producing, selecting, managing and promoting cultural goods, try to assert new classifications (cf. Maguiere/Mathews 2010). ${ }^{1}$ Haynes (2005: 368), for instance, in his study about the British world music industries highlights the "symbolic production via marketing, advertising and other forms of promotion in an attempt to shape the use and exchange value of cultural goods. « The intermediaries he talked to were critics for

1 Ironically, while central in Bourdieu's opus magnum on cultural consumption, the term »cultural intermediaries « does not occur in his works on the field of cultural production (Bourdieu 1993). 
magazines, newspapers, journals and books; creative directors, marketing personnel and $A \& R$ (artist and repertoire) representatives from world music labels; music producers and musicians from internationally acclaimed bands; BBC radio and TV producers; and, finally, academics and others involved in both the formal and informal study of music and culture from non-western contexts.

But which characteristics do these actors share and what functions do they fulfill in cultural industries? In my view, two features seem crucial to the notion of cultural intermediaries. The first important characteristic of jobs done by cultural intermediaries (and many other petit bourgeois occupations, by the way) is their low professionalization. Normally, cultural intermediaries do not need formal certificates or credentials to access this field. This openness makes positions in the cultural industries attractive for those who lack education for middle class professions (such as lawyers, medical doctors or chief executives, the so-called cadres). To quote Bourdieu:

»It can immediately be seen that, precisely by virtue of their actual and potential indeterminacy, positions which offer no guarantees but, in return, ask for no guarantees, which impose no specific condition of entry, especially as regards certificates, but hold out the promise of the highest profits for noncertified cultural capital, which guarantee no particular career prospects (of the type offered by the well-established occupations) but exclude none, not even the most ambitious, are adjusted in advance to the dispositions typical of individuals in decline endowed with a strong cultural capital imperfectly converted into educational capital, or rising individuals who have not obtained all the educational capital which, in absence of social capital, is needed to escape the most limited of the middle positions« (Bourdieu 1984: 355; italicized by A.G.).

As described later, among cultural intermediaries there are a lot of people with a middle class habitus (that is, a lot of incorporated cultural capital) but little tertiary education, that is, people without university degrees, university dropouts or holder of university degrees in humanities and the arts, which have little prestige and relevance for higher positions. Consequently, people in the creative industries very often build their careers on their ability to deal competently with symbolic forms, on their soft skills and especially on large and diverse networks, a wide spectrum of useful connections (cf. Angerer 2008; Baker/Hesmondhalgh 2011: 139-158).

Simultaneously, this very indetermination makes cultural intermediaries imagine themselves as existing outside the social order. To quote again Bourdieu (1984: 370): »Classified, déclassé, aspiring to a higher class, they see themselves as unclassifiable, >excluded<, >dropped out<, >marginal<, anything rather than categorized, assigned to a class, a determinate place in 
social space."Their inconsistency of status makes them sensitive to the non-established and obviously predestines them to reevaluate the »not-yetlegitimate (ibid.: 324; cf. Maguire/Matthew 2010: 4) They are those who in a Schumpeterian sense help »to assert new combinations (»neue Kombinationen durchsetzen «) by repackaging cultural creations (vgl. Schumpeter 1997 [1911]: 100). Many innovations in the culture industries were introduced to the markets through a process of reassessment of an allegedly debased cultural form as for instance photography, jazz, rhythm and blues, martial arts etc. People with an undefined, often marginal social status and a passion for questioning existing cultural hierarchies played an important role in this process. ${ }^{2}$

Thus, cultural intermediaries fulfill two crucial functions in cultural industries in general and on world music markets in particular: First, they support marginalized, non-established artists in getting access to relevant resources and institutions in the field. They provide performance opportunities, bring musicians into contact with each other, help produce records, promote them at radio stations, write about them in newspapers and magazines, award them with prizes - in short: they do everything necessary to establish a new cultural form in the majority market. Second, and more importantly, they frame or reframe these cultural productions by providing access to institutions.

Studies in different fields have shown how frames govern our perception. ${ }^{3}$ Recently, the frame concept was applied to innovation processes in cultural fields. Shyon Bauman (2007) has shown, that many artistic innovations were simply repackaged or reframed in order to be perceived as legitimate forms of expression and in order to succeed on majority markets. Cultural intermediaries use established frames in order to evoke resonance among the public. Similarly, the Balkan music intermediaries presented in the next part provide consumers with ready-made frames with which they can reinterpret and appropriate marginalized musics as legitimate. In contrast to Bauman (and others), who strictly distinguishes between resources and frames, I want to show how access to resources and the process of framing interact and reinforce each other. In assigning acts to predefined categories and genres (world music, jazz, etc.), supporting them with cul-

2 There are some obvious parallels in the description of the new cultural intermediaries by Bourdieu and the description of »the foreigner « by Georg Simmel and the "cosmopolitan « by Robert Merton respectively which may be worth elaborating on in more detail.

3 The frame concept was applied for instance to economics (Kahneman/Tversky 1984), social movement (Benford/Snow 2000), media (Entman 1993) and ethnicity (Esser 1999). 
turally marked resources (e.g. awards), presenting and marketing them through institutionalized channels (certain media, venues, labels, etc.) managers in the creative industries implicitly frame these cultural goods and hence steer their perception (cf. Gebesmair 2008: 144-151).

\section{The Advent of the Balkan Music Intermediaries ${ }^{4}$}

Let us now return to the Balkan music boom in Austria. Since the beginning of the New Millennium Austria has faced an enormous boom in Balkan Music productions and events. The figure below shows the annual number of Balkan events 1990 to 2009:

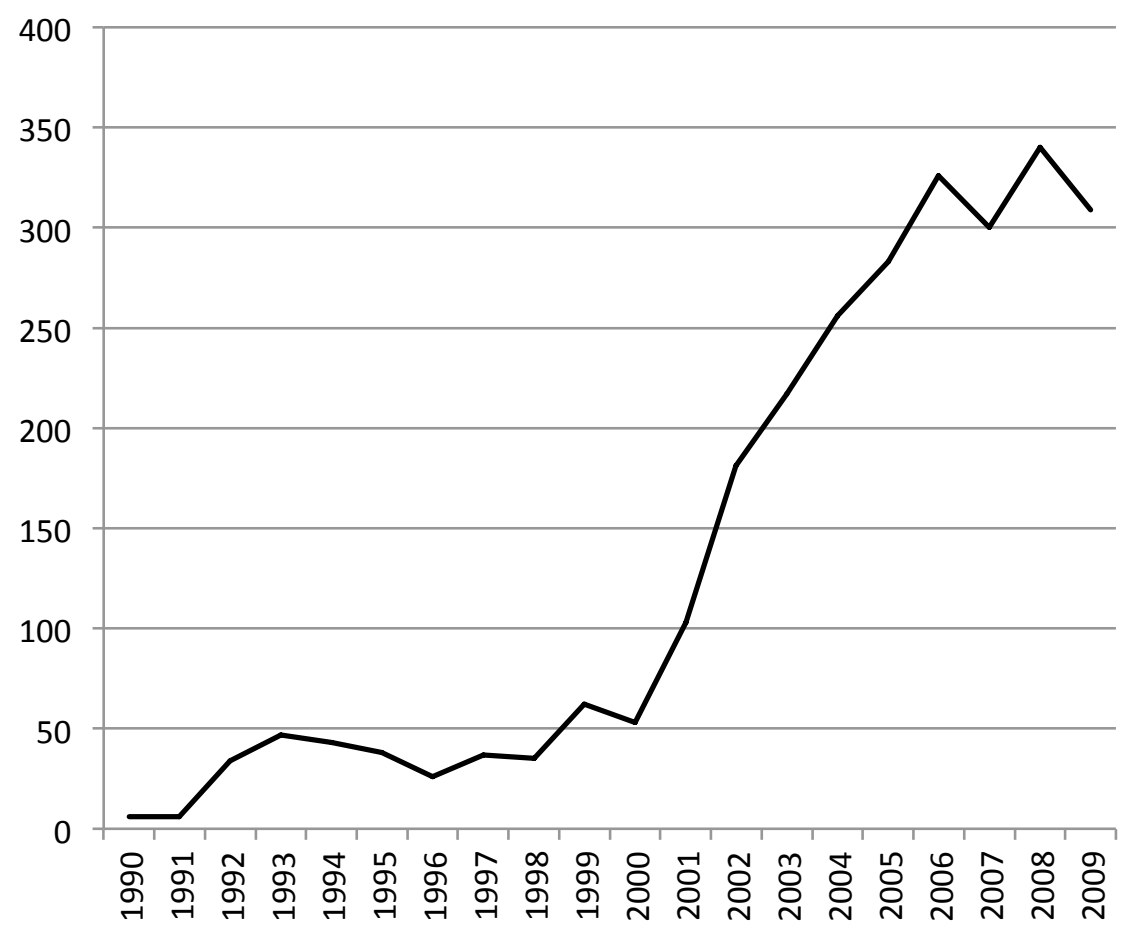

Figure 1: Number of events with reference to Balkan Music in Austria 1990-2009 (Sources: Announcements and reviews in 13 Newspapers and Magazines) ${ }^{5}$

All events explicitly referring to »Balkanmusik«, »Gypsy music « or »Balkan Brass «, to Balkan countries like Bulgaria, Serbia or Greece or to names of Balkan artists were counted as Balkan events. While during the 1990s there

4 The material presented in this chapter stems from a project carried out with Anja Brunner and Regina Sperlich and funded by the Austrian Science Funds under the Number P20791-G14. For more details see Gebesmair/Brunner/ Sperlich 2014.

5 Ibid.: 291. The 2009 value was projected from numbers for January to August. 
were about 50 events and less a year, for the first decade of the New Millennium we observed an extreme increase in Balkan Music events.

What we found surprising about this boom from a sociological point of view is the fact that it took Balkan music more than two decades to cross over from ethnic niche markets to a broader local audience. Balkan music had already been brought to Western-European centers in the 1970s and 1980 s by so-called suest-workers<. Recent studies have shown that immigrants began to build up a lively cultural infrastructure early. Music from their home countries was imported not just by media and records, but also by live performances (Hemetek 2001; Waldrauch/Sohler 2004). But it was not before the end of the century that Balkan music was marketed on a large scale to the German-speaking majority in Austria.

We assume the success of Balkan music is due to new forms of cultural intermediation. Therefore we have compared the popular music field before the outset of the Balkan boom with the period at the turn of the millennium.

The first, pre-boom crossovers of Balkan music to the majority markets were produced and marketed by musicians from Balkan countries, who came to Austria not as working migrants but mainly to study at Austrian universities. Lakis Jordanopoulos, born in the Greek city of Thessaloniki, had studied chemistry at the Vienna University of Technology before he formed the band Lakis \& Achwach in 1983, which focused on Mediterranean music. Marios Anastassiou came from Athens to Vienna in 1985 in order to take guitar lessons at the school of music and some years later began to perform traditional music from Greece together with the Greek-Austrian singer and baglama-player Juliana Rixinger as the duo Marios \& Julie. More explicitly from the Balkans was the music played by the Wiener Tschuschenkapelle. »Tschusch « is a pejorative designation of immigrants from South-Eastern Europe, which the band used ironically to make a political statement against xenophobia. The band was founded in 1989 by Slavko Ninić, who studied languages and sociology in Vienna and Zagreb.

All three acts, still active today, had strong ties to the local folk music scene from the beginning and cooperated with each other several times. They also framed their music in a similar way: The preservation and continuation of musical traditions was not only regarded as entertainment, but as a form of political articulation. For Lakis Jordanopoulos it was important to take a stand by performing traditional music »at times when skepticism against immigrants began to rise (Ergott 1997). The Wiener Tschuschenkapelle made its political stance against exclusion clear through its band name and, at least in their early years, Marios \& Julie showed an affinity to 
social causes with their interest in rembetiko. Furthermore, Jordanopoulos and Ninić were active in migration politics: Ninić worked for an information center for immigrants, Jordanopoulos was employed as a staff member for the minorities department of the Austrian public service broadcaster (ORF). In the 1990s they were frequent guests at the refugee festivity in Vienna. The musicians are obviously committed to an artistic concept that was widespread in the folk music scene of the 1970s and 1980s. Many of those, who called themselves »kritische Liedermacher « (critical song-writers) were close to political movements of the left and combined their musical practice with political engagement (Juhasz 1990).

Cultural intermediaries, as defined above, played a subordinate role during this period. Of course, these musicians were supported by several institutions, especially by some smaller venues, regional folk festivals and the independent label Extraplatte. However, they lacked those driving forces that characterize the practice of cultural intermediaries: access to institutions beyond their own closed communities and a frame that resonates within a larger public and, hence, helps to popularize a still marginalized cultural practice.

The steep increase in the number of Balkan events and of their coverage in Austrian media during the first decade of the $21^{\text {st }}$ century was prepared by two dynamics in the field of cultural production. The first was a considerable increase of educated immigrants from Southeastern and Eastern Europe coming to Austria in order to study at Austrian music schools. Some of them, as for instance Nataša Mirković-De Ro, escaped from the civil war in former Yugoslavia, others like Jovan Torbica or Sandy Lopičić came earlier, but almost all of them were lured by the high quality of musical education at Austrian universities. In fact, the highly prestigious music schools in Vienna and even more in Graz became hot spots of the emerging Balkan boom during the late 1990s.

The second driving force behind the Balkan boom, which is of greater importance, was the advent of only a handful of Balkan music intermediaries. One common feature exhibited by all was one Bourdieu (1984: 355365) described as typical for the new petit bourgeoisie and the new intermediaries in the cultural industries. Almost all of them possess a high amount of incorporated cultural capital, but lack higher formal education and credentials, which would provide them access to well-established occupations of the middle and upper class. Their career brought them to a diverse range of positions within the cultural industries, building a large network across organizational, geographical and cultural boundaries. And 
they frequently combine managerial functions at festivals, venues and record labels with writing for journals and magazines.

The first generation of Balkan music intermediaries who introduced Balkan music to a larger public in Austria as well as in other European countries was not from Austria. For instance, as mentioned above, the Rumanian ensemble Taraf de Haïdouks was rediscovered and broadly marketed by Stéphane Karo und Michel Winter, who worked for the Belgian art-rock label Crammed Discs. The Gypsy brass band Fanfare Ciocărlia was brought to Western Europe by the German artist's agents Henry Ernst and Helmut Neumann. Both groups performed several times in Austria from the late 1990s on and were crucial in the preparation of the Balkan Boom in Austria. Another Balkan music entrepreneur from abroad was even more important for the local Balkan music scene. Jean Trouillet, who worked as a writer and publisher after high school and who had several positions in the world music industry, released the first album of the Graz-located Sandy Lopicic Orkestar at Network Medien, a prominent German world music label.

The rise of the Sandy Lopicic Orkestar to one of the main actors of the Balkan boom illustrates how boundary spanning networks can serve as highly valuable resources: The tight-knit music scene in Graz helped Sandy Lopičić and his fellow musicians from the music school to establish close contacts to the local folk band deishovida. Its members were themselves graduates or dropouts from the music school in Graz and had been friends with Jean Trouillet for several years. Trouillet not only produced the first album of the Sandy Lopicic Orkestar in 2001, but also introduced them to the German Balkan pop act Shantel and, hence, provided access to completely new publics. Since 2004 members of the Sandy Lopicic Orkestar have supported Shantel's »Bucovina Club .

At this time, several Austrian cultural intermediaries entered the Balkan music scene: among them Richard Schuberth, who initiated the Balkan Fever Festival and made its program for several years, and Matthias Angerer, founder and manager of the ost klub. Again, both have large amounts of cultural capital with low formal credentials (Schubert studied social anthropology, Angerer quit his law courses at the University of Vienna to study film production in Los Angeles), both built their careers in the media and creative industries on network ties and not on formal education and both worked as writers and journalists, thus helping to define the emerging field. But, in which way did the presentation of Balkan music in the late 1990s and early 2000s differ from that of the Balkan music pioneers of the 1980s and early 1990s? How was Balkan music reframed? 
We observed two different framing strategies: On the first hand, Balkan music was presented as an art form within a highbrow institutional context. For instance, the Sandy Lopicic Orkestar arose from a theater production at the Schauspielhaus Graz, which integrated traditional Balkan music in one of its productions. Highbrow cultural institutions as the Radiokulturhaus or the Wiener Konzerthaus were increasingly booked for Balkan music concerts, and jazz, itself consecrated as an art form not before the 1950s (Lopez 2002), became an important reference for promoting Balkan music. Concert halls and jazz clubs transformed folk music into something to be consumed respectfully and contemplatively.

On the other hand, Balkan music was increasingly regarded as a vital and authentic form of pop music. While the pioneers stressed their commitment to traditions and presented their music as a form of a political statement, Balkan music at the turn of the millennium was appreciated for its vitality and immediacy. It was increasingly interpreted in ways we know from the rock music discourse. As Simon Frith has astutely put it in his analysis of the world music discourse:

»The difference at stake [when marketing world music, A.G.] wasn't between Western and non-Western music but, more familiarly, between real and artificial sounds, between the musically true and the musically false, between the authentic and the inauthentic musical experiences« (Frith 2000: 307; see also Regev 1997).

In this perspective, Balkan music (and world music in general) rejuvenated popular music in the same way rock music has rejuvenated popular music in the 1950s and 1960s. The folk music frame with its protective and political connotations was substituted for the rock music frame that directs the listeners' attention to the music's liveliness and authenticity of expression. ${ }^{6}$ Thus the brass band Fanfare Ciocărlia was praised for its imagination and the quality of their live performances and »their furious live blast appealing to punks and headbangers, jazz and funk fans, world music aficionados and those who simply love music that sounds absolutely unique (Asphalt Tango Production n.d.).

The ost klub with its focus on boisterous and tumultuous performances and parties provided a perfect platform for the new attitude to Balkan music and simultaneously confirmed the frame. Again, institutions themselves serve as strong frames. Performing at contemporary clubs and pop

6 Sociologists of social movements have highlighted the importance of aligning frames (Benford/Snow 2000). The more framing strategies correspond to existing ideologies and cultural practices the more they succeed. 
festivals governed the expectations and perceptions of listeners who increasingly regarded Balkan music as a new opportunity to regenerate pop culture.

\section{Conclusion}

Undoubtedly, the character of Balkan music has changed during the last decades. Most of the artists from the Austrian Balkan music scene adapted traditional forms to modern expectations by integrating Balkan music into jazz, rock and other current genres. Many of them came to Austria to study classical music or jazz and later reappropriated these musical traditions through contemporary interpretations. Insofar, conventional explanations of crossover success hold true for the Balkan boom, too. A growing number of listeners were interested in distant musical cultures and a handful of artists catered to the needs of the audience by making this music more familiar. But there are also counterexamples.

The artists of Taraf de Haïdouks or Fanfare Ciocărlia made few concessions to Western listening habits. Nevertheless, their music was reframed by being presented in elite or rock music contexts. Taraf de Haïdouks performed their first concert in the classical music hall, Konzerthaus Wien, Fanfare Ciocărlia in Vienna's most important rock music venue, Szene Wien. Through recontextualizing, traditional music becomes aligned with dominant ideologies and cultural practices and hence resonates with larger audiences.

In any case, new cultural intermediaries play an important role in communicating regional musics to listeners in majority markets: They provide access to institutions and thus help to redefine cultural practices in accordance with widespread frames. Without support by cultural intermediaries who are predestined to mediate between sharply marked off spheres Balkan music had not been heard of beyond its niche market. 


\section{Bibliography}

Angerer, Maria (2008). »Unter Freunden. Die sozialen Netzwerke von Alleinselbstständigen. «In: Nachhaltige Arbeit in der Wiener Kreativwirtschaft? Architektur - Design - Film - Internet - Werbung. Ed. by Helmut Eichmann and Helene Schiffbänker (= Kreativwirtschaft in Wien 1). Wien, etc.: LIT, pp. 135-154.

Asphalt Tango Production (n.d.). »Fanfare Ciocărlia: The Legends of Gypsy Brass.« In: Asphalt Tango Production; http://www.asphalt-tango.de/fanfare/artist.html (accessed 26.1.2015).

Hesmondhalgh, David / Baker, Sarah (2011). Creative Labour. Media Work in Three Cultural Industries. London, New York: Routledge.

Benford, Robert D. / Snow, David A. (2000). »Framing Processes and Social Movements: an Overview and Assessment.« In: Annual Review of Sociology 26, pp. 611-639.

Bourdieu, Pierre (1984). Distinction. A Social Critique of the Judgement of Taste. London, New York: Routledge.

Bourdieu, Pierre (1993). The Field of Cultural Production: Essays on Art and Literature. New York, Chichester: Columbia University Press.

Brackett, David (1994). "The Politics and Practice of >Crossover in American Popular Music 1963 to 1965. «In: The Musical Quarterly 78:4, pp. 774-797.

Broughton, Simon (2007). »Taraf de Haïdouks. «In: Songlines, June, pp. $46 \mathrm{f}$.

Buchanan, Donna A. (1997). »Review Essay: Bulgaria's Magical Mystère Tour: Postmodernism, World Music Marketing, and Political Change in Eastern Europe.« In: Ethnomusicology 41:1, pp. 131-157.

Collins, John / Richards, Paul (1989). »Popular Music in West Africa.« In: World Music, Politics and Social Change. Ed. by Simon Frith. Manchester, New York: Manchester University Press, pp. 12-46.

Connell, John / Gibson, Chris (2004). »World Music: Deterritorializing Place and Identity. «In: Progress in Human Geography 28:3, pp. 342-361.

Entman, Robert (1993). »Framing: Toward Clarification of a Fractured Paradigm.« In: Journal of Communication 43:4, pp. 51-58.

Ergott, Manfred (1997). "Lakis \& Achwach « [concert review]. In: Concerto 4, p. 60.

Esser, Hartmut (1999). »Die Situationslogik ethnischer Konflikte. In: Zeitschrift für Soziologie 28:4, pp. 245-262.

Featherstone, Mike (1991). Consumer Culture and Postmodernism. London, etc.: Sage.

Frith, Simon (2000). "The Discourse of World Music."In: Western Music and Its Others. Difference, Representation, and Appropriation in Music. Ed. by Georgina Born and David Hesmondhalgh. Berkeley, Los Angeles, London: University of California Press, pp. 305-322.

Garofalo, Reebee (1990). "Crossing Over: 1939-1989.« In: Split Image: African Americans in the Mass Media. Ed. by Jannette L. Dates and Williams Barlow. Washington, D.C.: Howard University Press, pp. 57-121.

Gebesmair, Andreas (2008). Die Fabrikation globaler Vielfalt. Struktur und Logik der transnationalen Popmusikindustrie (= texte zur populären musik 5). Bielefeld: transcript.

Gebesmair, Andreas / Brunner, Anja / Sperlich, Regina (2014). Balkanboom! Eine Geschichte der Balkanmusik in Österreich (= Musik und Gesellschaft 34). Frankfurt/M., etc.: Peter Lang. 
Haynes, Jo (2005). »World Music and the Search for Difference.«In: Ethnicities 5:3, pp. 365-385.

Hemetek, Ursula (2001). Mosaik der Klänge. Musik der ethnischen und religiösen Minderheiten in Österreich (= Schriften zur Volksmusik 20). Wien, etc.: Böhlau.

Hesmondhalgh, David (2006). »Bourdieu, the Media and Cultural Production.«In: Media, Culture and Society 28:2, pp. 211-231.

Juhasz, Christiane (1990). Politisches Engagement und Sozialkritik in der Popularmusik. Zur Musik kritischer Lieder in Österreich nach 1968. Dissertation, Universität Wien.

Kahneman, Daniel / Tversky, Amos (1984). »Choices, Values, Frames.«In: American Psychologist 39:4, pp. 341-350.

Lopes, Paul (2002). The Rise of a Jazz Art World. Cambridge: Cambridge University Press.

Regev, Motti (1997). »Rock Aesthetics and Musics of the World.«In: Theory, Culture \& Society 14:3, pp. 125-142.

Schuberth, Richard (2001). »Sandy Lopicic Orkestar.«In: Concerto 2:1; http:// www.concerto.at/arc/2-01/Titel.html (accessed 19.1.2014).

Schuberth, Richard (2007). »Der Balkan-Boom (aus der Sicht eines Mittäters).«In: Balkan Fever Festival 2009; http://www.balkanfever.at/2009/index.php/derbalkan-boom-aus-der-sicht-eines-mittaeters (accessed 19.1.2014).

Schumpter, Joseph (1997). Theorie der wirtschaftlichen Entwicklung. Eine Untersuchung über Unternehmergewinn, Kapital, Kredit, Zins und den Konjunkturzyklus. Berlin: Duncker \& Humboldt [Erstveröffentlichung 1911].

Taylor, Timothy D. (1997). Global Pop: World Music, World Markets. New York, London: Routledge.

van der Lee, Pedro (1998). »Sitars and Bossas: World Music Influences.«In: Popular Music 17:1, pp. 45-70.

Waldrauch, Harald und Karin Sohler (2004). Migrantenorganisationen in der Großstadt. Entstehung, Strukturen und Aktivitäten am Beispiel Wiens (= Wohlfahrtspolitik und Sozialforschung 14). Frankfurt/M., etc.: Campus.

\begin{abstract}
During the first decade of the new millennium Balkan music gained considerable popularity in Austria. The number of Balkan events and their coverage in domestic media increased significantly. This article deals with the question why do some musics cross over to Western markets and others do not? Using material from the Austrian world music scene this article shows how so-called cultural intermediaries helped Balkan music and musicians to attract new listeners. They provided access to crucial resources and framed the music in a way that resonates with a broader audience.
\end{abstract}

